\title{
ANTIBACTERIAL ACTIVITY OF THE PHLOROTANNINS DIECKOL AND PHLOROFUCOFUROECKOL-A FROM ECKLONIA CAVA AGAINST PROPIONIBACTERIUM ACNES
}

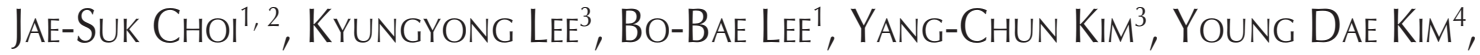 \\ Yong-Kı Hong ${ }^{5}$, Kwang Keun Cho and In SOOn ChOI ${ }^{1,7,8}$ \\ ${ }^{1}$ RIS Center, Industry-Academic Cooperation Foundation, Silla University, Busan, Republic of Korea \\ ${ }^{2}$ Department of Bio-Food Materials, Silla University, Sasang-gu, Busan, Republic of Korea \\ ${ }^{3}$ Gijang Local Products Co. Ltd., Gijang-eup, Gijang-gun, Busan, Republic of Korea \\ ${ }^{4}$ East Sea Fisheries Research Institute, National Fisheries Research \& Development Institute, Gangneung, Republic of Korea \\ ${ }^{5}$ Department of Biotechnology, Pukyong National University, Nam-gu, Busan, Republic of Korea \\ ${ }^{6}$ Department of Animal Resources Technology, Gyeongnam National University of Science and Technology, \\ Jinju, Gyeongnam, Republic of Korea \\ ${ }^{7}$ Depertment of Biological Science, Silla University, Sasang-gu, Busan, Republic of Korea \\ ${ }^{8}$ Corresponding author: ischoi@silla.ac.kr
}

\begin{abstract}
Methanol extract of the marine brown alga Ecklonia cava has been shown to exhibit antimicrobial activity against Propionibacterium acnes. To identify the compounds conferring this antimicrobial activity, methanol extract was fractionated using silica-gel column chromatography by increasing solvent polarity, and the antimicrobial activities of each fraction were determined in terms of the minimum inhibitory concentration. Hexane, diethyl ether, acetone, ethyl acetate, acetonitrile, methanol, and water fractions were generated, with the acetone fraction exhibiting the greatest antibacterial activity (minimum inhibitory concentration $=156 \mu \mathrm{g} / \mathrm{mL}$ ). The acetone fraction was further purified by Sephadex LH-20 column chromatography and reverse-phase HPLC using an Alltima C18 column with an $\mathrm{H}_{2} \mathrm{O}-\mathrm{MeOH}$ linear gradient from 30 to $100 \%$. Two peaks were eluted at 18.1 (P1) and 23.8 (P2) min, both of which exhibited marked antibacterial activity (minimum inhibitory concentration $=39 \mu \mathrm{g} / \mathrm{mL}$ for both). The structures of these compounds were determined on the basis of ${ }^{1} \mathrm{H}$ and ${ }^{13} \mathrm{C}$ nuclear magnetic resonance data and, through comparison with published data, can be phloroglucinol derivatives dieckol (P1) and phlorofucofuroeckol-A (P2). These results suggest that phlorotannins derived from E. cava have antimicrobial activity against $P$. acnes, and so may be useful as natural additives in antiacne cosmetics and pharmaceutical products.
\end{abstract}

Keywords: dieckol, minimum inhibitory concentration, natural additives, phlorofucofuroeckol-A, phlorotannins.

Resumen: Se conoce que el extracto de metanol del alga parda marina Ecklonia cava presenta actividad antimicrobiana contra Propionibacterium acnes. Para identificar los compuestos que confieren esta actividad antimicrobiana se fraccionó el extracto de metanol, usando cromatografía en columna de sílica gel, mediante el aumento de la polaridad del disolvente. La actividad antimicrobiana de cada fracción se determinó en términos de la concentración mínima inhibitoria. Las fracciones de hexano, éter dietílico, acetona, acetato de etilo, acetonitrilo, metanol y agua fueron producidas. La fracción de acetona presentó la mayor actividad antibacteriana (concentración mínima inhibitoria $=156 \mu \mathrm{g} / \mathrm{mL}$ ). Con base en este resultado, la fracción de acetona se purificó por cromatografía en columna en LH-20 Sephadex y HPLC de fase inversa usando una columna Alltima C18 con un gradiente lineal de $\mathrm{H}_{2} \mathrm{O}-\mathrm{MeOH}$ de 30 a 100\%. Dos picos se eluyeron a 18.1 (P1) y 23.8 (P2) min, ambos tuvieron actividad antibacteriana marcada (concentración mínima inhibitoria $=39 \mu \mathrm{g} / \mathrm{mL}$ para ambos). La estructura de estos compuestos se determinó sobre la base de ${ }^{1} \mathrm{H}$ y ${ }^{13} \mathrm{C}$ de resonancia magnética nuclear y, mediante la comparación con valores publicados, éstos pueden ser derivados de floroglucinol diecol (P1) y florofucofuroecol-A (P2). Los resultados sugieren que florotaninos derivados de E. cava tienen actividad antimicrobiana frente a $P$. acnes, y por lo tanto, pueden ser útiles como aditivos naturales en los cosméticos anti-acné y los productos farmacéuticos.

Palabras clave: aditivos naturales, concentración mínima inhibitoria, diecol, florofucofuroecol-A, florotaninos.

A cne is a chronic inflammatory condition whose clinical presentation can range from a mild comedonal form to severe cystic acne of the face, chest, and back. Factors that contribute to the development of acne include hormonal imbalance, bacterial infection, stress, food, or spoiled cosmetic application (Zu et al., 2010; Park et al., 2004). Propionibac- 
terium acnes is a gram-positive, anaerobic microorganism, which has been recognized as a key factor in the development of inflammatory acne, due to its ability to metabolize sebaceous triglycerides into fatty acids, which attract neutrophils (Jappe, 2003).

Antibiotics are regularly prescribed for the treatment of acne vulgaris; however, antibiotic resistance is increasingly common in many dermatologic infections. The development of antibiotic resistance is multifactorial, involving host characteristics, the mechanism of antibiotic activity, how the antibacterial is used, and environmental factors (Eady, 1998; Swanson, 2003). To address the growing problem of antibiotic resistance, medicinal plants have been investigated as alternative treatments (Chomnawang et al., 2005; Choi et al., 2011).

A previous study of methanol extracts of Ecklonia cava showed considerable antibacterial activity against microorganisms frequently involved in acne inflammation, such as Propionibacterium acnes, with minimal side effects (Choi et al., 2011). Of the 57 species of seaweed screened for their potential antimicrobial, the methanol extracts of E. cava exhibited the highest activity against $P$. acnes, showing 0.31 $\mathrm{mg} / \mathrm{mL}$ of the minimum inhibitory concentration (MIC) value. However, the active compounds were not identified. In this study, we examined crude extracts of E. cava by solvent polarity, gel chromatography, and HPLC with the aim of isolating and identifying the active compounds.

\section{Materials and methods}

Algae. The edible marine brown alga Ecklonia cava Kjellman was collected from the coast of Jeju Island, South Korea, in 2009 and washed three times with tap water to remove salt. Algae were air-dried for five days at room temperature using an electric fan and ground in a mill and passed through a 500 mesh sieve. The sieved material was stored at $-20{ }^{\circ} \mathrm{C}$ until use.

Extraction. The sieved powder $(1 \mathrm{~kg})$ was suspended in $80 \%$ methanol (3 L) for two days to extract soluble compounds. The extract was then filtered through Toyo No. 2 filter paper under reduced pressure. This extraction procedure was repeated three times and the extracts were combined. The combined $80 \%$ methanol extract was concentrated and dried to a dark-green residue $(54.9 \mathrm{~g})$ under reduced pressure in a vacuum evaporator.

Purification of antimicrobial compounds. To fractionate according to polarity, the dried extract was then suspended in a $5 \mathrm{~mL}$ aliquot of hexane, subjected to silica gel chromatography $(3.6 \mathrm{~cm}$ i.d. $\times 40 \mathrm{~cm}$, Silica Gel $60,15-40 \mu \mathrm{m}$, Merck, Germany), and eluted successively with $300 \mathrm{~mL}$ of different solvents: hexane, diethyl ether, acetone, ethyl acetate, acetonitrile, methanol, and water. The acetone fraction $(2.87 \mathrm{~g})$, which exhibited the greatest antibacterial activity, was further purified by Sephadex LH-20 chromatography $(1.5 \mathrm{~cm}$ i.d. $\times 50 \mathrm{~cm}$, Sigma, St. Louis, MO) with $1 \mathrm{~L}$ of methanol to yield four sub-fractions containing the desired active compounds. Each $10 \mathrm{~mL}$ fraction was collected at a flow rate of $1 \mathrm{~mL} / \mathrm{min}$. Of these, sub-fraction 66-75 (583.2 $\mathrm{mg}$ ), which exhibited the most potent antibacterial activity, was subjected to reverse-phase HPLC purification using a Waters 600 HPLC system (Waters, Milford, MA, USA) and an Alltima C18 column ( $10 \mathrm{~mm}$ i.d. $\times 250 \mathrm{~mm}$, Alltech Inc., IL, USA) with $5 \mu \mathrm{m}$ particles. Elution was performed at a flow rate of $4.0 \mathrm{~mL} / \mathrm{min}$ using a $\mathrm{H}_{2} \mathrm{O}-\mathrm{MeOH}$ linear gradient, from 30 to $100 \%$ for $20 \mathrm{~min}$, and maintained for $20 \mathrm{~min}$. The UV detector was set at $290 \mathrm{~nm}$. The two peaks (P1 and P2), which exhibited the most potent antibacterial activity, were isolated. Each eluted compound was dried under a stream of nitrogen gas obtained from a $\mathrm{N}_{2}$ generator (G4010E, Domnick Hunter, England; less than 100 ppm oxygen content).

Nuclear Magnetic Resonance (NMR). Two compounds of P1 and P2 were analyzed using NMR. ${ }^{1} \mathrm{H}$ NMR (400 MHz) and ${ }^{13} \mathrm{C}$ NMR (100 MHz) spectra were recorded on a JNMECP 400 NMR spectrometer (JEOL, Tokyo, Japan), using a DMSO-d6 solvent peak (2.50 ppm in ${ }^{1} \mathrm{H}$ and $39.5 \mathrm{ppm}$ in ${ }^{13} \mathrm{C}$ NMR) as an internal reference standard. MS spectra were obtained on a JMS-700 spectrometer (JEOL, Japan). The structures of the purified compounds were identified and confirmed to be identical to the spectral data in Nakamura et al. (1996), Fukuyama et al. (1990), and Kang et al. (2003).

Culture of microorganism. Propionibacterium acnes (KCTC 3314) was obtained from the Korean Collection for Type Cultures (KCTC; Daejeon, South Korea) and was incubated in CM 1135 brain heart infusion (BHI) agar (Oxoid Ltd.,

Table 1. MIC of the solvent polarity fractionate against Propionibacterium acnes tested by broth microdilution assay. The results are shown as average values from three separate experiments (MIC in $\mu \mathrm{g} / \mathrm{mL}$ ) and "-" is no inhibition at $10 \mathrm{mg} / \mathrm{ml}$.

Minimum inhibitory concentration $(\mu \mathrm{g} / \mathrm{mL})$

\begin{tabular}{lllllllll}
\cline { 2 - 7 } & \multicolumn{9}{c}{ Silica gel chromatography } & & & \\
\cline { 2 - 7 } & Crude methanol & Hexane & Diethyl ether & Acetone & Ethyl acetate & Acetonitrile & Methanol & Water \\
\hline P. acnes & 312 & - & - & 156 & $>625$ & $>625$ & 312 & - \\
\hline
\end{tabular}


Hampshire, England) containing $1 \%$ glucose at $37{ }^{\circ} \mathrm{C}$ for $72 \mathrm{~h}$ under anaerobic conditions using the Bactron Anaerobic Chamber ${ }^{\mathrm{TM}}$ system (SHEL LAB, USA). Gas conditions were $\mathrm{H}_{2} 5 \%, \mathrm{CO}_{2} 5 \%$, and $\mathrm{N}_{2} 90 \%$.

Determination of MIC value. Antimicrobial activity was determined by broth microdilution assay, following the guideline of the National Committee for Clinical and Laboratory Standards (NCCLS) for anaerobic bacteria M11A6 (NCCLS, 2004) in a 96 U-shaped well microplate. Propionibacterium acnes inocula were prepared from $24 \mathrm{~h}$ broth cultures, and suspensions adjusted to 0.5 McFarland solution turbidity. Samples were first diluted to the highest concentration $(10 \mathrm{mg} / \mathrm{mL})$ to be tested, followed by serial twofold dilutions to generate a concentration range of 19.5 to $10 \mathrm{mg} / \mathrm{mL}$. All MIC tests were performed using three independent replicates.

\section{Results}

Isolation of antibacterial fractions. Methanol extract of Ecklonia cava showed considerable antibacterial activity. To identify compounds conferring antimicrobial activity, the methanol extract of E. cava $(54.9 \mathrm{~g})$ were further fractionated by silica-gel column chromatography using increasing solvent polarity. The yield of each solvent fraction was hexane $(0.16 \mathrm{~g})$, diethyl ether (2.95 g), acetone (3.34 g), ethyl
Table 2. MICs and purification factors of Ecklonia cava fractions against Propionibacterium acnes by broth microdilution assay. The results are shown as average values from three separate experiments (MIC in $\mu \mathrm{g} / \mathrm{mL}$ ) and " ${ }_{-}$" is not determined.

\begin{tabular}{|c|c|c|c|c|}
\hline $\begin{array}{l}\text { Extract and } \\
\text { fraction type }\end{array}$ & $\begin{array}{l}\mathrm{MIC} \\
(\mu \mathrm{g} / \mathrm{mL})\end{array}$ & $\begin{array}{l}\text { Purification } \\
\text { factor }\end{array}$ & Weight & $\begin{array}{l}\text { Yield } \\
(\%)\end{array}$ \\
\hline E. cava powder & - & - & $1 \mathrm{Kg}$ & 100 \\
\hline Methanol extract & 312 & 1 & $54.9 \mathrm{~g}$ & 5.49 \\
\hline $\begin{array}{l}\text { Acetone fraction } \\
\text { (Silica gel } \\
\text { chromatography) }\end{array}$ & 156 & 2 & $2.87 \mathrm{~g}$ & $2.87 \times 10^{-1}$ \\
\hline $\begin{array}{l}\text { Fraction No. 66-75 } \\
\text { (Sephadex gel } \\
\text { chromatography) }\end{array}$ & 78 & 4 & $583.2 \mathrm{mg}$ & $5.832 \times 10^{-2}$ \\
\hline Dieckol (HPLC) & 39 & 8 & $9.2 \mathrm{mg}$ & $9.2 \times 10^{-4}$ \\
\hline $\begin{array}{l}\text { Phlorofucofuroeckol-A } \\
\text { (HPLC) }\end{array}$ & 39 & 8 & $6.4 \mathrm{mg}$ & $6.4 \times 10^{-4}$ \\
\hline
\end{tabular}

acetate $(0.49 \mathrm{~g})$, acetonitrile (1.58 g), methanol (38.56 g) and water $(4.32 \mathrm{~g})$. The acetone fraction exhibited the greatest activity against Propionibacterium acnes as indicated by the MIC (Table 1). To isolate the compounds conferring antibacterial activity, the acetone fraction was further purified by Sephadex LH-20 gel column chromatography using methanol as the eluent, with each fraction separated into 10

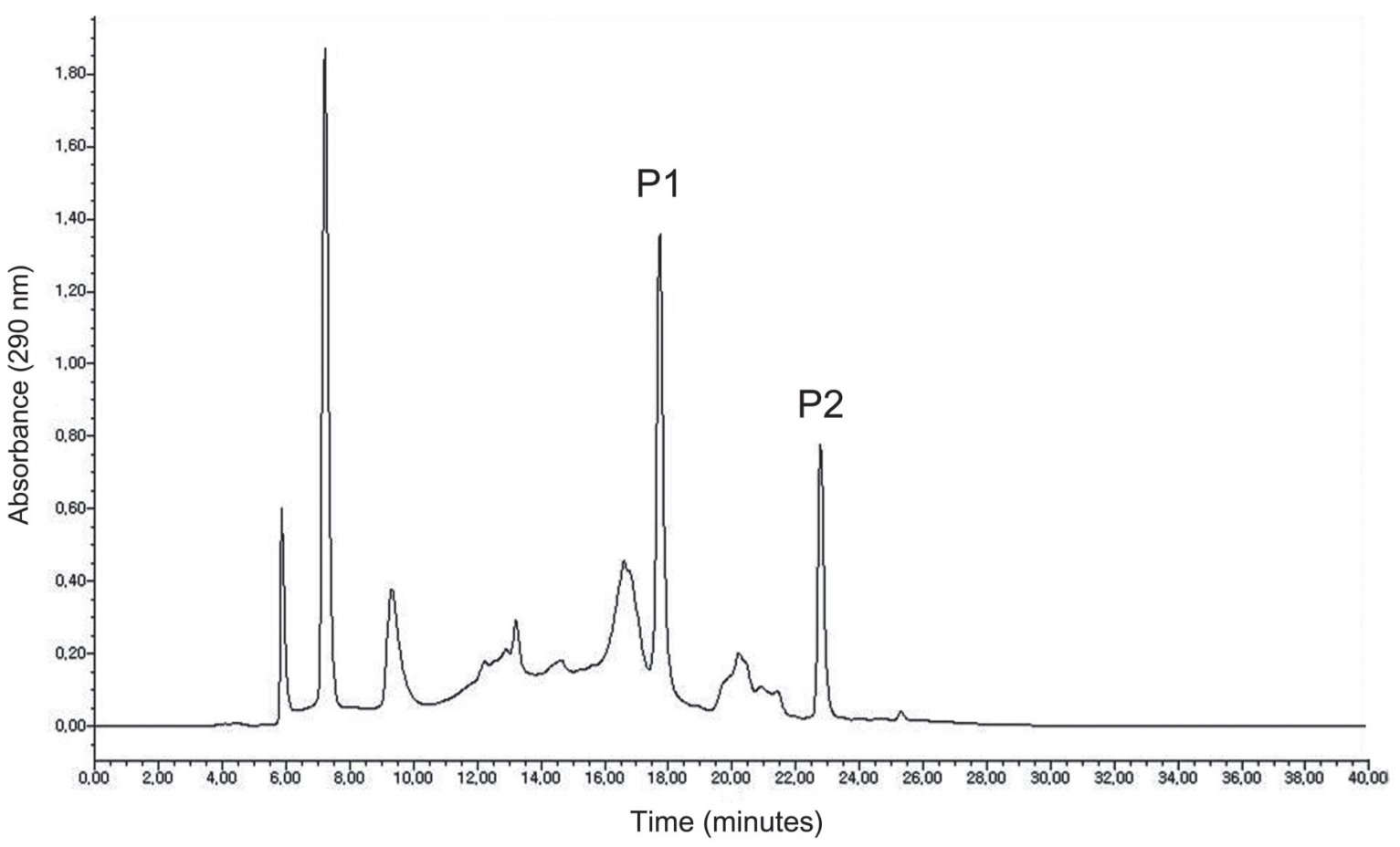

Figure 1. HPLC chromatogram of fraction Nos. 66-75, isolated by Sephadex gel chromatography. Elution was performed at a flow rate of $4.0 \mathrm{~mL} / \mathrm{min}$ using a $\mathrm{H}_{2} \mathrm{O}-\mathrm{MeOH}$ linear gradient from 30 to $100 \%$ for $20 \mathrm{~min}$, and maintained for 20 min. The UV detector was set at $290 \mathrm{~nm}$. 

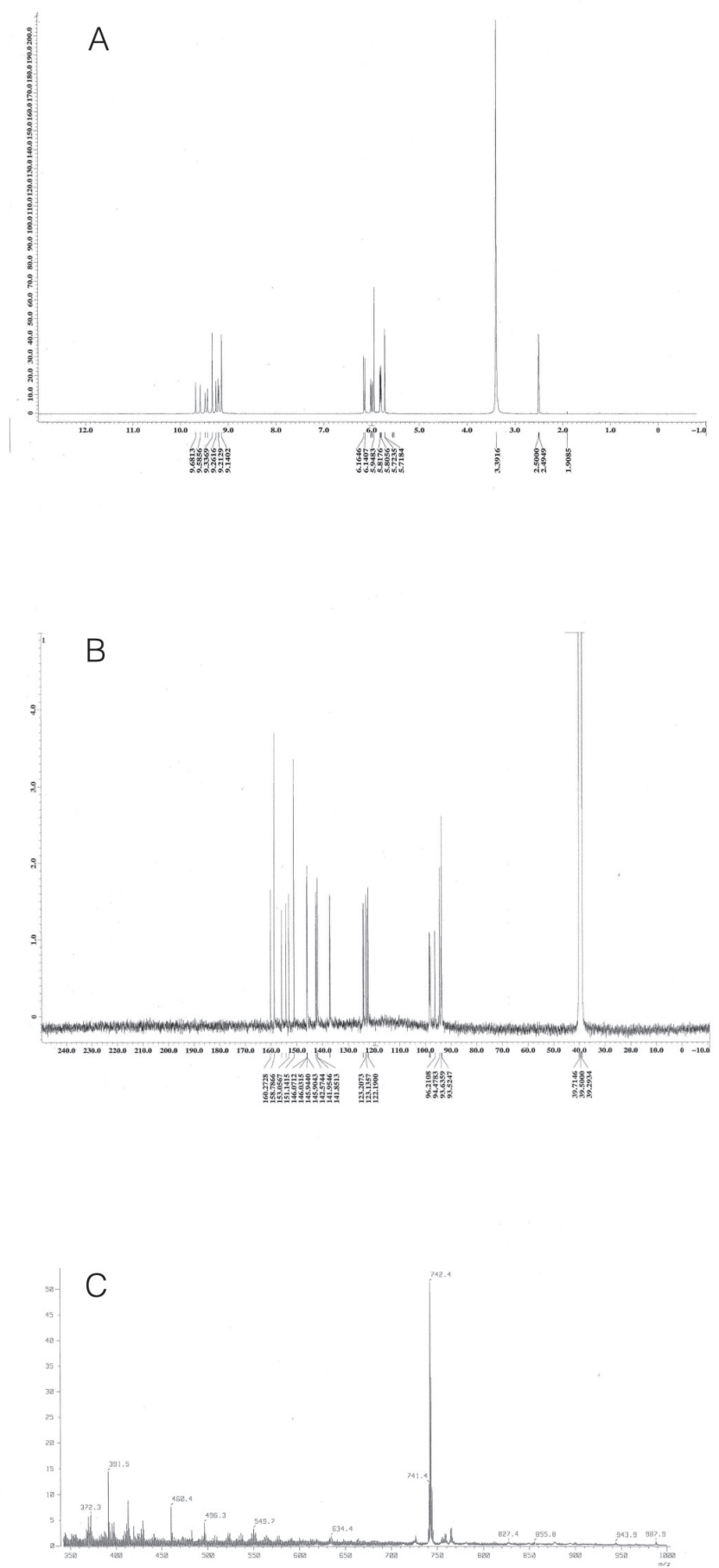

Figure 2. A) ${ }^{1} \mathrm{H}$ NMR spectrum, B) ${ }^{13} \mathrm{C}$ NMR spectrum, and C) LRFAB-MS spectrum of peak 1 isolated by reverse-phase, highperformance liquid chromatographic separation.

$\mathrm{mL}$ aliquots. Fraction 66-75 showed the greatest antibacterial activity and was therefore, collected $(583.2 \mathrm{mg})$ for further isolation.

The active fraction was subjected to HPLC using an Alltima C18 reverse-phase column (Alltech Inc., IL, USA). Elution was performed using a linear gradient from 30 to $100 \%$ methanol for $20 \mathrm{~min}$ and maintained for $20 \mathrm{~min}$, yielding two peaks at $t_{\mathrm{R}}$ (retention time) $=18 \mathrm{~min}(\mathrm{P} 1 ; 9.2 \mathrm{mg})$ and $t_{\mathrm{R}}=24 \mathrm{~min}(\mathrm{P} 2 ; 6.4 \mathrm{mg})$. Both fractions showed marked activity against Propionibacterium acnes (Table 2).

Identification of antibacterial compounds. The purified compounds were analyzed in a Low Resolution Mass Spectrometer JMS-700 spectrometer (JEOL, Japan). The two peaks were identified as dieckol (P1) and phlorofucofuroeckol-A (P2) on the basis of NMR and mass spectrophotometer data, as well as through comparison with previously reported values (Figures 1-3). NMR readouts for compounds P1 and P2 were as follows:

P1 (dieckol).- light brown powder; ${ }^{1} \mathrm{H}$ NMR (DMSO- $d_{6}$, $400 \mathrm{MHz}) \delta 9.68$ (1H, s, OH-9), 9.58 (1H, s, OH-9"), 9.48 (1H, s, OH-4"), 9.43 (1H, s, OH-4), 9.33 (2H, s, OH-3",5") , $9.26(1 \mathrm{H}, \mathrm{s}, \mathrm{OH}-2$ "), $9.21(1 \mathrm{H}, \mathrm{s}, \mathrm{OH}-2), 9.19(1 \mathrm{H}, \mathrm{s}, \mathrm{OH}-$ 7'), 9.14 (2H, s, OH-3', 5'), 6.16 (1H, s, H-3”), 6.14 (1H, s, $\mathrm{H}-3), 6.02(1 \mathrm{H}, \mathrm{d}, J=3.0 \mathrm{~Hz}, \mathrm{H}-8), 5.98(1 \mathrm{H}, \mathrm{d}, J=2.7 \mathrm{~Hz}$, H-8"), 5.94 (1H, s, H-2"',6"'), $5.82(1 \mathrm{H}, \mathrm{d}, J=2.7 \mathrm{~Hz}, \mathrm{H}-$ 6), $5.81(1 \mathrm{H}, \mathrm{d}, J=2.7 \mathrm{~Hz}, \mathrm{H}-600), 5.79(1 \mathrm{H}, \mathrm{t}, J=2.0 \mathrm{~Hz}$, H-4'), 5.72 (2H, d, $\left.J=2.0 \mathrm{~Hz}, \mathrm{H}-2^{\prime}, 6^{\prime}\right){ }^{13} \mathrm{C}$ NMR (DMSO$\left.d_{6}, 100 \mathrm{MHz}\right) \delta 122.1$ (s, C-1), 146.0 (s, C-2), 98.2 (d, C3), 141.8 (s, C-4), 123.1 (s, C-4a), 142.3 (s, C-5a), 93.5 (d, C-6), 154.2 (s, C-7), 98.0 (d, C-8), 145.9 (s, C-9), 123.2 (s, C-9a), 137.2 (s, C-10a), 160.2 (s, C-1'), 93.6 (d, C-2'), 158.7 (s, C-3'), 96.2 (d, C-4'), 158.7 (s, C-5'), 93.6 (d, C6'), 122.2 (s, C-1"), 145.9 (s, C-2"), 98.2 (d, C-3"), 141.9 (s, C-4"), 123.1 (s, C-4a"), 142.5 (s, C-5a"), 93.8 (d, C-6"), 153.0 (s, C-7"), 98.4 (d, C-8"), 146.0 (s, C-9"), 122.5 (s, C-9a"), 137.0 (s, C-10a"), 155.8 (s, C-1'"), 94.4 (d, C-2'”), 151.1 (s, C-3"'), 124.0 (s, C-4"”), 151.1 (s, C-5"'), 94.4 (d, C-6"') ; LRFAB-MS m/z 742.36 [M]+ (Figure 2).

P2 (phlorofucofuroeckol-A).- light brown powder; ${ }^{1} \mathrm{H}$ NMR (DMSO- $\left.d_{6}, 400 \mathrm{MHz}\right) \delta 10.13(1 \mathrm{H}, \mathrm{s}, \mathrm{OH}-14), 9.85$ $(1 \mathrm{H}, \mathrm{s}, \mathrm{OH}-4), 9.85(1 \mathrm{H}, \mathrm{s}, \mathrm{OH}-10), 9.43(1 \mathrm{H}, \mathrm{s}, \mathrm{OH}-2)$, 9.20 (2H, s, OH-3",5"), 9.17 (2H, s, OH-3',5'), $8.21(1 \mathrm{H}$, s, OH-8), $6.72(1 \mathrm{H}, \mathrm{s}, \mathrm{H}-13), 6.43(1 \mathrm{H}, \mathrm{s}, \mathrm{H}-9), 6.29(1 \mathrm{H}$, s, H-3), 5.84 (2H, t, $J=2.0 \mathrm{~Hz}, \mathrm{H}-4$ ', 4") $5.76(2 \mathrm{H}, \mathrm{d}, J=$ $2.0 \mathrm{~Hz}, \mathrm{H}-2$ ', 6'), 5.72 (2H, d, $J=2.0 \mathrm{~Hz}, \mathrm{H}-2 ", 6$ "); ${ }^{13} \mathrm{C}$ NMR (DMSO- $d_{6}, 100 \mathrm{MHz}$ ) $\delta 122.5$ (s, C-1), 146.9 (s, C2), 98.2 (d, C-3), 141.9 (s, C-4), 122.5 (s, C-4a), 133.9 (s, C-5a), 103.1 (s, C-6), 103.3 (s, C-7), 146.4 (s, D-8), 99.0 (d, C-9), 150.3 (s, C-10), 120.0 (s, C-11), 149.4 (s, C-11a), 150.7 (s, C-12a), 94.8 (d, C-13), 144.7 (s, C-14), 126.3 (s, C-14a), 136.8 (s, C-15a), 160.2 (s, C-1'), 93.7 (s, C-2'), 158.8 (s, C-3'), 96.3 (d, C-4'), 158.9 (s, C-5'), 93.7 (s,C6'), 159.9 (s, C-1"), 93.4 (d, C-2"), 158.8 (s, C-3"), 96.4 (d, C-4"), 158.8 (s, C-5"), 93.4 (d, C-6"); LRFAB-MS m/z $602.38[\mathrm{M}+\mathrm{H}]^{+}$(Figure 3).

Antibacterial activity. The MIC of the Ecklonia cava methanol extract against Propionibacterium acnes was $312 \mu \mathrm{g} / \mathrm{mL}$; the MIC of the acetone fraction isolated by silica gel chro- 

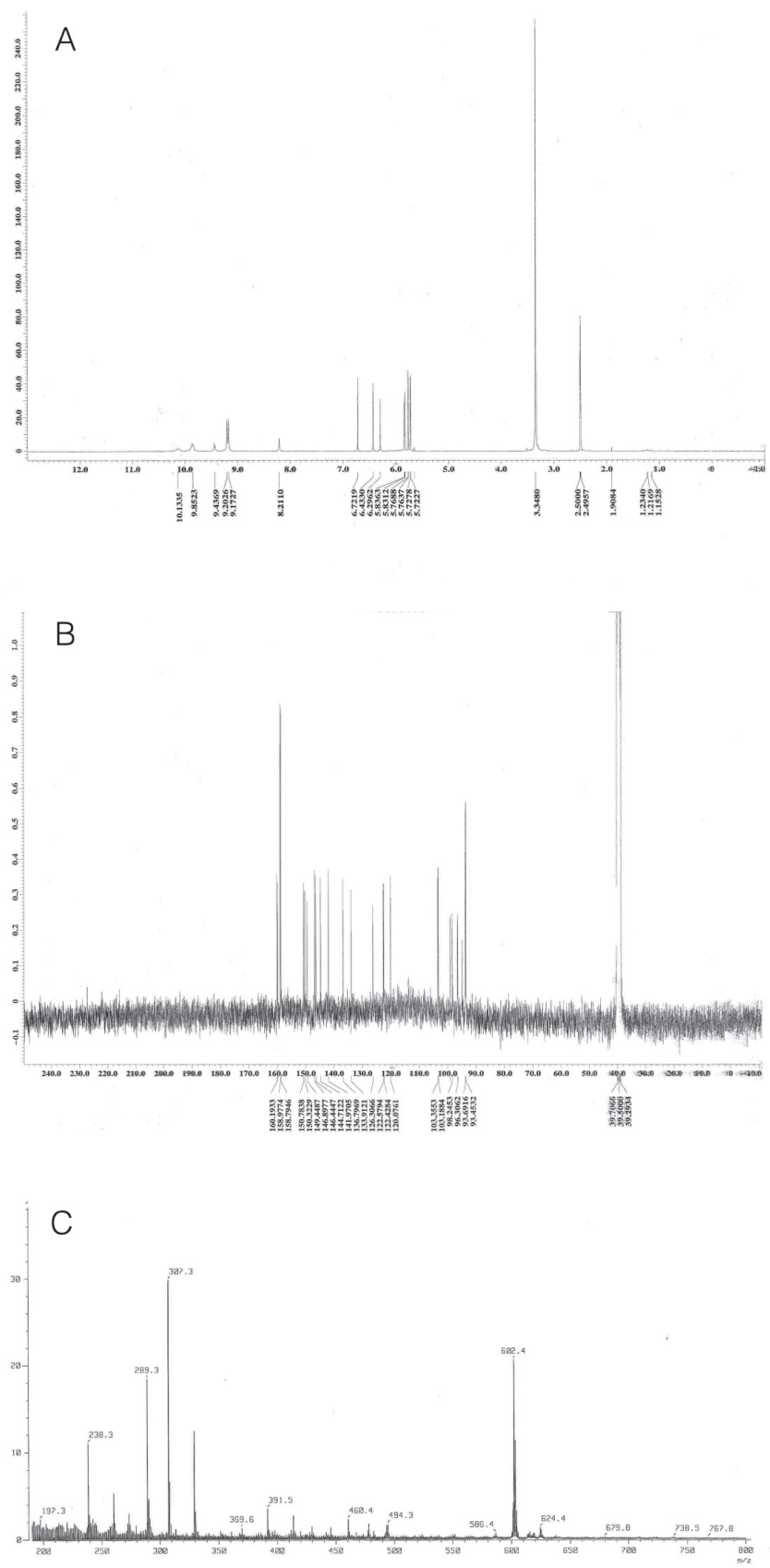

Figure 3. A) ${ }^{1} \mathrm{H}$ NMR spectrum, B) ${ }^{13} \mathrm{C}$ NMR spectrum, and C) LRFAB-MS spectrum of peak 2 isolated by reverse-phase, highperformance liquid chromatographic separation.

matography was $156 \mu \mathrm{g} / \mathrm{mL}$. The MIC of fraction No. 66-75 purified by Sephadex gel column chromatography was 78 $\mu \mathrm{g} / \mathrm{mL}$. The MICs for purified dieckol and phlorofucofuroeckol-A against $P$. acnes were both $39 \mu \mathrm{g} / \mathrm{mL}$ (Tables 1 , $2)$. The yields of dieckol and phlorofucofuroeckol-A from Ecklonia cava were $9.2 \times 10^{-4} \%$ and $6.4 \times 10^{-4} \%$, respectively (Table 2).

\section{Discussion}

Ecklonia cava is a large, perennial brown alga (Laminariaceae) that is widely distributed throughout the subtidal regions of South Korea. Because of the economic and ecological importance of this species, it has been studied extensively (Bolton and Anderson, 1994; Wijesinghe and Jeon, 2012). Ecklonia cava has been used as a source of fucoidan, fucan sulfate, and phlorotannins, which have known antitumor, anticoagulant, antioxidant, and antithrombin properties (Heo et al., 2005; Ahn et al., 2007; Eom et al., 2012; Wijesinghe and Jeon, 2012). Furthermore, E. cava has long been used throughout China and Korea in traditional herbal medicines for the treatment of cancer and inflammation $(\mathrm{Xu}$ et al., 2002).

Among the active compounds isolated from Ecklonia cava, phlorotannins are the most important. Chemical analysis of E. cava revealed that phlorotannins, oligomeric polyphenols of the phloroglucinol class compounds, are the main constituents responsible for the biological activity of E. cava; they include eckol, dieckol, bieckol and phlorofucofuroeckol-A (Eom et al., 2012). Structurally, phlorotannins are oligomers and polymers of 1,3,5-trihydroxybenzene (phloroglucinol), which are formed via the polyketide pathway (Ragan and Glombitza, 1986; Waterman and Mole, 1994). They have shown broad therapeutic potential, including anti-diabetes, antioxidation, radiation protection, anti-cancer, anti-HIV, and anti-allergenic activities (Li et al., 2011).

In our previous study, Ecklonia cava was used as the starting material to identify compounds exhibiting unique antibacterial activities against microorganisms frequently involved in acne inflammation, such as Propionibacterium acnes (Choi et al., 2011). In this study, we further fractioned the E. cava methanol extract using silica gel chromatography, Sephadex gel column chromatography, and HPLC. Fractions were then analyzed by NMR and the active components identified. Based on the Low Resolution Fast Atom Bombardment-Mass Spectrometry (LRFAB-MS) data, and through comparison of ${ }^{1} \mathrm{H}$ and ${ }^{13} \mathrm{C}$ NMR results in Naka-
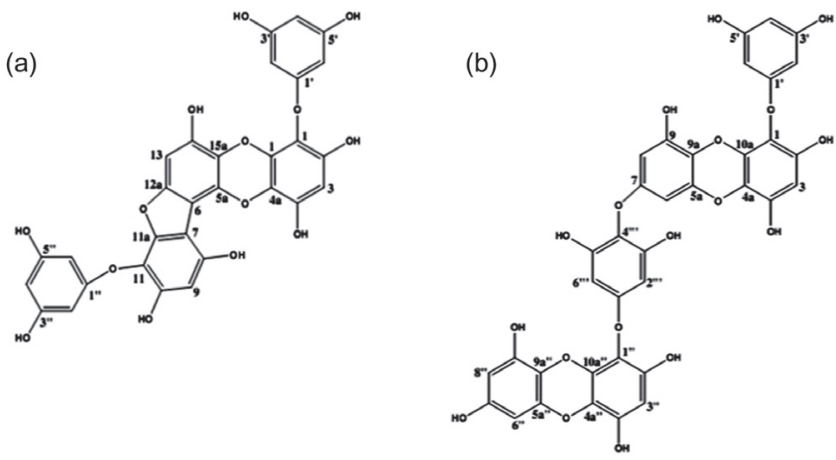

Figure 4. Chemical structures of (A) dieckol, and (B) phlorofucofuroeckol-A. 
mura et al. (1996), Fukuyama et al. (1990), and Kang et al. (2003), the active compounds were identified as dieckol and phlorofucofuroeckol-A.

Dieckol and phlorofucofuroeckol-A are phlorotannin derivatives of brown algae. The antibacterial activities of phlorotannins against a range of pathogenic bacteria have been demonstrated (Eom et al., 2012). They showed antimicrobial effect against food-borne pathogenic bacteria, antibiotic resistance bacteria, and human tinea pedis fungus. Although many studies have examined the antimicrobial activities of phlorotannins isolated from marine algae, we focused specifically on the isolation and identification of antimicrobial compounds active against acne-causing bacteria. The grampositive bacterium Propionibacterium acnes ATCC 6919 was selected based upon its ability to cause acne. The MICs of dieckol and phlorofucofuroeckol-A against $P$. acnes were both $39 \mu \mathrm{g} / \mathrm{mL}$.

In addition to its antibacterial properties, dieckol purified from Ecklonia cava has been shown to exhibit fungicidal activity (MIC $=148 \mathrm{mg} / \mathrm{mL}$ ) against Trichophyton rubrum, a causative agent of dermatophytic nail infections in humans (Lee et al., 2010). Dieckol isolated from E. stolonife$r a$ exhibits strong anti-methicillin-resistant Staphylococcus aureus (MRSA) activity, with MICs of 32-64 $\mu \mathrm{g} / \mathrm{mL}$ (Lee et al., 2008).

Phlorofucofuroeckol-A purified from Eisenia bicyclis inhibits MRSA at concentrations $>32-64 \mu \mathrm{g} / \mathrm{mL}$ (Eom, 2012). Phlorofucofuroeckol-A purified from E. kurome exhibits bactericidal activity against Campylobacter jejuni, Escherichia coli, Salmonella enteritidis, Salmonella typhimurium, and Vibrio parahaemolyticus at concentrations $>800.0 \mu \mathrm{g} / \mathrm{mL}$ (Nagayama et al., 2002).

Structurally, phlorotannins are oligomers and polymers of 1,3,5-trihydroxybenzene (phloroglucinol), which are formed via the polyketide pathway (Ragan and Glombitza, 1986; Waterman and Mole, 1994). Although the relationship between the structure and antimicrobial activity of phlorotannins is poorly understood, the physiological activity may depend on the degree of polymerization of phlorotannin derivatives (Ragan and Glombitza, 1986; Eom et al., 2012). It has been reported that eckol, dieckol, bieckol, and phlorofucofuroeckol-A are the most abundant phlorotannin compounds in Ecklonia cava (Li et al., 2011). In this study, two phlorotannins, dieckol and phlorofucofuroeckol-A, representing $9.2 \times 10^{-4} \%$ and $6.4 \times 10^{-4} \%$ of the methanol extract, respectively, were shown to exhibit antibacterial activity.

\section{Conclusions}

The data suggest that phlorotannins have pronounced antimicrobial activity against acne-causing bacteria. Moreover, no cytotoxic effects were observed following oral administration of phlorotannins at a dosage of $170-1,500 \mathrm{mg} / \mathrm{kg} / \mathrm{day}$ for 14 days in mice (Nagayama et al., 2002). Together, these results suggest that the phlorotannins dieckol and phlorofucofuroeckol-A isolated from Ecklonia cava could be useful antibiotic agents for both cosmetic and pharmaceutical applications.

\section{Acknowledgments}

This research was supported by the Korea Small and Medium Business Administration (Grants No.00036130), Republic of Korea, and was also supported by the Global Healthcare Industry RIS Center, Ministry of Knowledge Economy, Republic of Korea. KKC was also supported by Gyeongnam National University of Science and Technology Grant 2012, Republic of Korea, and Priority Research Centers Program through the National Research Foundation of Korea (NRF) funded by the Ministry of Education, Science and Technology (2012-006683). We are grateful to reviewers for helpful comments.

\section{Literature cited}

Ahn G.N., Kim K.N., Cha S.H., Song C.B., Lee J., Heo M.S., Yeo I.K., Lee N.H., Jee Y.H., Kim J.S., Heu M.S. and Jeon Y.J. 2007. Antioxodant activities of phlorotannins purified from Ecklonia cava on free radical scavenging using ESR and $\mathrm{H}_{2} \mathrm{O}_{2}-$ mediated DNA damage. European Food Research and Technology 226:71-79.

Bolton J.J. and Anderson R.J. 1994. Ecklonia. In: Akatsuka I. Ed. Biology of Economic Algae, pp. 385-406, SPB Academic Publishing, The Hague.

Choi J.S., Bae H.J., Kim S.J. and Choi I.S. 2011. In vitro antibacterial and anti-inflammatory properties of seaweed extracts against acne inducing bacteria, Propionibacterium acnes. Journal of Environmental Biology 32:313-318.

Chomnawang M.T., Surassmo S., Nukoolkarn V.S. and Gritsanapan W. 2005. Antimicrobial effects of Thai medicinal plants against acne-inducing bacteria. Journal of Ethnopharmacology 101:330-333.

Eady E.A. 1998. Bacterial resistance in acne. Dermatology 196:5966.

Eom S.H. 2012. Anti-MRSA (methicillin-resistant Staphylococcus aureus) substance isolated from Eisenia bicyclis and its action mechanism. Ph.D. Dissertation, Pukyong National University, Busan. 45 pp.

Eom S.H., Kim Y.M. and Kim S.K. 2012. Antimicrobial effect of phlorotannins from marine brown algae. Food and Chemical Toxicology 50:3251-3255.

Fukuyama Y., Kodama M., Miura I., KinZyo Z., Mori H., Nakayama Y. and Takahashi M.1990. Anti-plasmin inhibitor. VI. Structure of phlorofucofuroeckol A, a novel phlorotannin with both dibenzo-1,4-dioxin and dibenzofuran elements, from Ecklonia kurome OKAMURA. Chemical and Pharmaceutical Bulletin 38:133-135.

Heo S.J., Park P.J., Park E.J., Kim S.K. and Jeon Y.J. 2005. Antioxidant activity of enzymatic extracts from a brown seaweed Ecklonia cava by electron spin resonance spectrometry and comet assay. European Food Research and Technology 221:41-47. 
Kang H.S., Chung H.Y., Jung J.H., Son B.W. and Choi J.S. 2003. A new phlorotannin from the brown alga Ecklonia stolonifera. Chemical and Pharmaceutical Bulletin 51:1012-1014.

Jappe U. 2003. Pathological mechanisms of acne with special emphasis on Propionibacterium acnes and related therapy. Acta Dermato-Venereologica 83:241-248.

Lee M.H., Lee K.B., Oh S.M., Lee B.H. and Chee H.Y. 2010. Antifungal activities of dieckol isolated from the marine brown alga Ecklonia cava against Trichophyton rubrum. Journal of the Korean Society for Applied Biological Chemistry 53:504-507.

Lee D.S., Kang M.S., Hwang H.J., Eom S.H., Yang J.Y., Lee M.S., Lee W.J., Jeon Y.J., Choi J.S. and Kim Y.M. 2008. Synergistic effect between dieckol from Ecklonia stolonifera and $\beta$-lactams against methicillin-resistant Staphylococcus aureus. Biotechnology and Bioprocess Engineering 13:758-764.

Li Y.X., Wijesekara I., Li Y. and Kim S.K. 2011. Phlorotannins as bioactive agents from brown algae. Process Biochemistry 46:2219-2224.

Nagayama K., Iwamura Y., Shibata T., Hirayama I. and Nakamura T. 2002. Bactericidal activity of phlorotannins from the brown alga Ecklonia kurome. Antimicrobial Agents and Chemotherapy 50:889-893.

Nakamura T., Nagayama K., Uchida K. and Tanaka R. 1996. Antioxidant activity of phlorotannins isolated from brown alga $E i$ senia bicyclis. Fisheries Science 62:923-926.
NCCLS. National Committee for Clinical Laboratory Standards. 2004. Methods for antimicrobial susceptibility testing of anaerobic bacteria. NCCLS Document M11-A6, NCCLS, Wayne.

Park J., Lee J., Jung E., Park Y., Kim K., Park B., Jung K., Park E., Kim J. and Park D. 2004. In vitro antibacterial and anti-inflammatory effects of honokiol and magnolol against Propionibacterium sp. European Journal of Pharmacology 496:189-195.

Ragan M.A. and Glombitza K.W. 1986. Phlorotannins, brown algal polyphenols. In: Round F.E. and Chapman D.J. Eds. Progress in Psychological Research Vol. 4, pp. 129-241, Biopress Ltd., Bristol.

Swanson J.K. 2003. Antibiotic resistance of Propionibacterium acnes in acne vulgaris. Dermatology Nursing 15:359-362.

Waterman P.G. and Mole S. 1994. Analysis of Phenolic Plant Metabolites. Blackwell Scientific Publications, Oxford.

Wijesinghe W.A.J.P. and Jeon Y.J. 2012. Exploiting biological activities of brown seaweed Ecklonia cava for potential industrial applications: a review. International Journal of Food Sciences and Nutrition 63:225-235.

Xu N., Fan X., Han L., Lin W. and Zeng C. 2002. Study on the antibacterial activities of the ethanol extracts of seaweed. Oceanologia et Limnologia Sinica 33:265-270.

Zu Y., Yu H., Liang L., Fu Y., Efferth T., Liu X. and Wu N. 2010. Activities of ten essential oils towards Propionibacterium acnes and PC-3, A-549 and MCF-7 cancer cells. Molecules 15:3200-3210.

Received: June 17th, 2013

Accepted: October 12th, 2013 